\title{
Genetic improvement of forest tree species
}

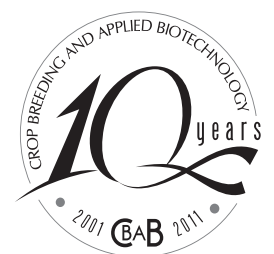

BA $B$ CROP BREEDING AND $\{3$

Teotônio Francisco Assis ${ }^{1 *}$ and Marcos Deon Vilela de Resende ${ }^{2}$

Received 10 March 2011

Accepted 28 May 2011

\begin{abstract}
Brazilian forestry sector is considered one of the most developed in the world, being the base for important industrial segments which use wood as raw material. Tree breeding has played an important role on improving the competitiveness of Brazilian forestry-based companies, especially for its positive reflexes on increasing adaptation, forestry productivity and wood quality. In spite of the importance of other forest trees for the economy, such as Schizolobium, Araucaria, Populus and Hevea, the main genera under genetic improvement in the country are Eucalyptus, Pinus, Acacia and Tectona. They are used by industries like pulp and paper, siderurgy, tannin, chips for exportation and lumber, constituting an important source of revenues for the Brazilian's economy, besides their positive social and environmental impacts. This paper presents a generic approach to genetic improvement aspects of these four major genera currently undergoing breeding in Brazil.
\end{abstract}

Key words: breeding, eucalyptus, Pinus, black wattle, teak.

\section{INTRODUCTION}

The Brazilian forestry sector, with more than $6,302,000$ ha planted is recognized and valued for its economic, social, and environmental importance to the country. It generates annual revenues of over $\mathrm{R} \$ \$ 52$ billion and tax collection around $\mathrm{R} \$ 8.8$ billion. It is an important generator of income for the country, with exports exceeding US $\$ 5.8$ billion. It provides employment to over 4,713,000 workers, benefiting more than 11 million people (ABRAF 2010).

Several exotic species have been of interest for the Brazilian forest sector, mainly those of the following genera: Eucalyptus, with 4,969,000 ha of forest plantations; Pinus, with 1,868,000 ha; Acacia, with 182,000 ha; and Tectona, with 58,800 ha (ABRAF 2010). These four genera are the most important in planted area, playing a major role in the national economic scenario. Other genera are also outstanding, such as timber producers Schizolobium, Araucaria and Populus and non-timber, such as Hevea.

\section{Eucalyptus}

Eucalyptus belongs to the division Angiospermae, class dicotyledon, order Myrtales, family Myrtaceae and genus Eucalyptus. The Eucalyptus genus has about 600 species, with almost all being native of Australia (except for E. urophylla, native to Indonesia, and E. deglupta, to Indonesia and Papua New Guinea). Among the most important species for Brazil, only two occur naturally outside Australia: E. urophylla, native to Indonesia (mainly the islands of Flores and Timor) and E. tereticornis, which occours in Australia and also Papua New Guinea.

The cultivation of eucalypt trees is of great importance to Brazil. It is the base for supplying raw materials, for large forest-based industrial enterprises, such as pulp and paper and charcoal for siderurgy. It is also used for other purposes, such as: lumber, poles, bio-energy, fences, etc. Thus, it is one of the most important revenue sources for the country, and contributes to environmental and native

\footnotetext{
${ }^{1}$ Assistech Ltda. Av. Reis Magos, 587, Condomínio Vila Castela, 34.000-000, Nova Lima, MG, Brazil.*E-mail: assisteo@terra.com.br
} 
species conservation via minimization of exploitation pressure on indigenous forest resources.

Introduced in the country in the early twentieth century, eucalypt has experienced significant genetic improvement over the years. Annual genetic gains of around $1 \%$ have been obtained. Initially, more promising species were identified for a variety of planting environments. From the 1960s until the 1980s, provenances or populations and species tests were emphasized. After 1980, progeny tests and intra population recurrent selection programs (IRS) were intensified (Kageyama and Vencovsky 1983). Since 1990, intensive hybridization programs were implemented, and after 2000, reciprocal recurrent selection (RRS) programs were initiated for hybrid breeding between diverging species. Details of breeding programs until the 1990s are presented by Assis (1996) and Ferreira and Santos (1997). During the breeding process, planting transition also occurred via seminal for seedlings obtained via cloning.

Eucalyptus breeding in Brazil is mainly practiced by pulp, paper and steel industries. Multipurpose breeding is also conducted by several industrial companies and by Embrapa Florestas. Other institutions contributing to eucalypt breeding are the universities UFV/SIF, ESALQ/ USP/IPEF, UFLA, UFPR and UNESP, generating theses and studies on this topic. Some of them also provide improved seeds.

At the early stages of eucalypt breeding in Brazil, species and populations from Australia were extensively evaluated and selected under various environmental conditions, for several traits of economic interest. Since the confirmation that inter-specific hybrids express heterosis (Assis 1996, 2000, 2001) and also based on the evolution of cloning techniques (Assis et al. 1992, Xavier and Comério 1996, Higashi et al. 2000), production and development of clones based on inter-specific hybrids has been adopted as a general strategy. Currently, the vast majority of eucalypt plantations in Brazil have been carried out with clones derived from hybrids. Several strategies based on hybridization have been used for the production of candidate clones. Today, breeding is based on parent selection and crosses made within RRS (Recurrent Reciprocal Selection) programs between divergent populations and also with IRS (Intra-population Recurrent Selection) in synthetic hybrid population from crosses between elite clones with incorporation of new elite clones, at each generation. This last procedure has been called Intrapopulation Recurrent Selection in Synthetic Population
(IPRSSP). This population is re-synthesized' every generation via controlled crossings (Resende and Barbosa 2005). Recently, studies on wide genomic selection have been carried out, showing a high potential for eucalyptus breeding (Resende et al. 2008, Fonseca et al. 2010, Grattapaglia and Resende 2010).

Besides volumetric productivity, the wood technological properties are essential characteristics in breeding programs today. In the case of pulp production, three characteristics can be described as fundamental in the economic aspect of the industrial productive process: pulp productivity per planted area (function of volumetric increment, wood density and pulp yield), wood production cost and wood lignin content.

For charcoal production, breeding aims to increase carbon productivity per hectare. This variable is related to volume, wood density and gravimetric yield. Besides these characteristics, charcoal mechanical resistance and granulometry are important for its industrial use.

Besides volumetric growth, the major wood production characteristics for veneer and sawmill, are the tendency to splitting and problems related to drying such as fiber collapse, warping, curling and spiraling. These characteristics are important for the industrial use of logs, a factor still lacking in eucalypt utilization.

Other essential features in industrial silviculture are: adaptation, tree shape, number and distribution of branches, bifurcation and resistance to pests, diseases, frost, drought and wind. Climatic adaptation refers mainly to adaptation to rainfall and temperature. In some regions, tolerance to cold and frost is a key factor, whereas in others, tolerance to excessive heat and water stress is an extremely necessary feature. In many germplasm, these two characteristics, resistance to cold and drought are positively correlated.

\section{Pinus}

Pinus species relevant to Brazil are native to mainly North and Central Americas. Species of this genus were introduced in Brazil around 1936. About 1.9 million hectares of Pinus have been planted, with over one million only with the species Pinus elliottii and Pinus taeda. Pinus breeding programs are also developed by private companies with support from public research institutions (Resende 1999).

The main species of the genus Pinus, genetically improved in Brazil are listed below with their respective uses and aptness regions (Resende 1999): 
- Long fiber pulp \& paper and sawn timber in subtropical climates: Pinus elliottii, Pinus taeda.

- Long fiber Pulp \& paper and sawn timber in tropical climates: Pinus caribaea, Pinus oocarpa, Pinus tecunumanii, Pinus patula (for not very hot regions and of high altitude), Pinus maximinoi.

- Long fiber pulp \& paper and sawn timber, in regions of transition between tropical and subtropical climates: Pinus tecunumanii, Pinus patula and Pinus maximinoi.

- Resin production: Pinus elliottii.

In addition to the 100 botanical species present in two subgenera $($ Haploxilon $=27$ species and Diploxilon $=$ 73 species) there is also possibility of hybridization, as long as the crossings remain restricted to each group, being able to be crossed, e.g.,: P. caribaea hondurensis x P. caribaea bahamensis, $P$. carbaea $\times$. tecunumanii and $P$. oocarpa x P. patula.

High rates of genetic gain have been obtained for the character volumetric production in Pinus and it has been possible to produce trees with more straight stems, lower number of bifurcations, and lower number of thick branches, leading to a better industrial utilization of the wood especially for furniture making.

Among the species most cultivated in Brazil are: i) subtropical species: Pinus taeda (the most cultivated Pinus species in Brazil) and Pinus elliotii (also used for resin extraction), ii) tropical species: Pinus caribaea var. hondurensis (representing around $70 \%$ of plantations with tropical Pinus) and Pinus oocarpa (representing approximately $15 \%$ of tropical plantations with Pinus).

The most common strategy used in the breeding of Pinus species has been the intra-population recurrent selection (IRS), but intra-specific controlled crosses have also become a common practice in some of these programs. The existence of functional heterosis (Assis 2000) at family level has been observed in P. taeda. This activity is being useful to capture benefits from Specific Combining Ability through controlled mass pollination, which seeks to maximize crossings between pairs of genotypes presenting superior combination. On the other hand, cloning programs of juvenile plants from these families are beginning to be developed for the implantation of forestry families.

These two strategies are producing important gains, but the possibility of cloning individuals is, undoubtedly, more attractive, in view of the possibility of exploring the variability within families. The great difficulty in cloning adult Pinus species lies in the impossibility of promoting rejuvenation via basal sprouts, as it is done with eucalyptus.
Thus, somatic embryogenesis has been a tool capable of generating individual clones. Its use is increasingly widespread, although there are operational difficulties in the commercial production of seedlings produced by this technique.

Somatic embryogenesis has also an important potential role in the cloning of hybrid plants. Several crosses have been performed among Pinus species, indicating a high potential to produce superior individuals. However, since the hybrid families are formed by crossing heterozygous plants, they are heterogeneous. Thus, individual cloning via somatic embryogenesis is crucial to take advantage of the commercial superiority of individual hybrids within these families.

P. taeda minicutting should be important to complement and enable individual cloning via somatic embryogenesis, at least until more suitable techniques are developed for mass production of the selected clones. It is currently a necessary step in the multiplication of clones regenerated from somatic embryos and it is much cheaper than other cloning methods, such as in vitro micro-propagation.

Currently, headways have been made in reducing the breeding cycles of Pinus. Due to the long period required for completing the breeding cycles, the main Pinus breeding programs in Brazil are still in transition for the third breeding generation. Early selection is currently performed in five years. The onset of the reproductive period was also reduced with early flowering induction via top-grafting. Normally, seed orchards which are not in use serve as a basis for grafting early selected materials, where flowering occurs one year after grafting. Old grafts are either pruned to a height of five meters approximately, with graft being performed in the shoots, or grafting is simply done on the apical branches of the canopy of mature grafts. Since these are trees that have reached their reproductive capacity much earlier, this characteristic is transferred to the young grafted material, inducing its early flowering.

\section{Black wattle}

Black wattle (Acacia mearnsii) belongs to the Leguminosae family, Mimosoideae subfamily. It is native to Australia and cultivated mainly in South Africa, Brazil and China, at altitudes ranging from $850 \mathrm{~m}$ up to the sea level in temperate and subtropical climate, with mean temperature in the coldest month between 0 and $5{ }^{\circ} \mathrm{C}$. It can endure several frosts per year and absolute minimum 
temperatures of $\left(-11^{\circ} \mathrm{C}\right)$. It has the ability to fix nitrogen through symbiosis with bacteria of the genus Rhizobium.

It is mainly used for tannin extraction (for hide and skin tanning), but other uses include the production of fuel wood for energy and charcoal and the supply of raw material for pulp industries. Today, with the export of wood chips to Japan, its timber became an extra source of profit for producers as well as a major generator of foreign exchange. In Brazil, it is grown in Rio Grande do Sul and the main characters of interest for breeding are wood and tannin production and resistance to the disease gomosis. Black wattle was originally introduced in Brazil in 1930 from seeds collected in South Africa and only in the 1980s Australian provenances and progenies were introduced, made by Embrapa Forestry and tannin-producing companies.

The population, which constitutes the Brazilian land race, does not present good possibilities for breeding due to the existing low genetic variability. In this case, the best approach is to develop breeding programs, using seeds from the best trees in the provenance tests, and also through the acquisition of seeds (at the progeny level) from the provenances Batemans Bay and Cann River Orbost, for tests in frost-free regions and from Cooma and Mount Rix, for regions with possible frost occurrences.

Breeding methods are based on seed production areas and seedling seed orchards. Clonal seed orchards formation has been hampered by the difficulty in producing clones, either by grafting or rooting.

There is still no information on the levels of dominance associated with the main characters of economic importance (tannin and wood production). This fact, associated with non-utilization of operational clonal plantations, has led to the adoption of IRS programs in Brazil, South Africa and China (Resende 2002).

Nevertheless, cloning of Acacia mearnsii has proved to be viable. The main difficulty lies in rescuing (field cloning) to obtain rejuvenated shoots. Stump sprouting of black wattle is inadequate, and even when sprouting after cutting is possible, oxidation of substances in the bark, probably tannin, ends up killing the sprouted buds. Thus, it has been more appropriate to rescue black wattle selected trees by inducing basal sprouting in standing trees. This can be accomplished by opening clearings, allowing the selected trees to receive light from all sides, or by forcing the trees to incline to an approximate angle of $45^{\circ}$ from the ground. In both cases, sprouts are emitted along the trunk, permitting selection of those closest to the ground in order to achieve a higher degree of tissue juvenility.
Clonal tests implanted by the company Tanac SA, with consultancy provided by UFPR, showed clones with $70 \%$ superiority, compared to commercial seeds. Although preliminary, the results obtained show that cloning tends to be the propagation method to be used to increase tannin and wood productivity, and to solve the gomosis problems in Acacia in Brazil.

\section{Teak}

Teak (Tectona grandis L. f.) is a tropical forest deciduous tree species, belonging to the Verbenaceae family. It is predominantly allogamous, with crossing rate around 95 to $98 \%$. Thus, breeding strategies customarily used in the breeding of other allogamous forest species can be applied to this species.

In Brazil, especially in Mato Grosso, the first commercial plantings took place in the early 1970s in Caceres. Although official records are lower, its planted area today is around 100,000 hectares. In recent years, teak plantations have expanded to northern Mato Grosso and southern Para. Teak breeding aspects based on Costa and Resende 2001, Costa et al. (2007) are presented below.

Apparently, there are no well-developed teak breeding programs in Brazil; thus, genetic variation between and within populations has not been adequately explored (Costa and Resende 2001). Thus, the importance of provenance, progeny and clones tests is emphasized to accelerate teak breeding.

Teak presents certain peculiarities that are obstacles to genetic improvement: seed production per tree is low, (what makes it difficult to carry out progeny tests), low number of seedlings, around 5, is produced from 100 seeds; controlled pollination is difficult; and long vegetative period before flowering (over 5 tears) a fact that makes the breeding cycle longer. However, the economic returns of breeding programs are significant in view of the high value of its timber.

Teak improvement programs in Thailand have been conducted since 1960 and have intensified after 1965 with the creation of the Teak Improvement Center - TIC in Ngao, province of Lampang. Since then, the TIC is developing provenance testing, selection of superior trees, and techniques for vegetative propagation, establishing seed production areas, clone banks and clone seed orchards.

The TIC has conducted clonal tests to better evaluate the superior trees selected. In this case, clone tests have replaced the progeny tests in view of the difficulties in producing seedlings, as previously reported. Provenance 
tests and genetic parameter estimates have been reported in ongoing works in India.

In Costa Rica (Central America), with the advancement of the industrial teak plantations in the region, it became imperative to incorporate genetic improvement as a fundamental tool to achieve production targets. Currently, there is a consistent teak breeding program based on cloning which is worth-mentioning, developed by the Costa Rica Forest Genetic Conservation and Improvement Cooperative (GenFores).

Specifically in teak breeding, the design of "parejas" within blocks was proposed by Dr. Olman Murillo (a researcher at the Technological Institute of Costa Rica), aiming to evaluate timber species such as teak, for a long period, before and after thinning, leaving only a plant from the pair or "pareja". The objective is to allow the estimation of family $x$ block interactions so as to distinguish from the environmental effects of the plots and also to allow the experiment to remain roughly balanced, with plants approximately equidistant after thinning. This tends to minimize the effects of differentiated competition after thinning.

Teak breeding in Costa Rica is conducted by a forest breeding cooperative of 12 companies. It is based on an experimental network consisting of four experiments arranged in a randomized block design with six replications, 28 families of half-siblings and three pairs of plants per replication. At three years of age each "pareja" is thinned to one plant, with three plants remaining per progeny per block.

In the teak breeding project in Costa Rica, block $\mathrm{x}$ family interaction has been shown to be non significant for the growth traits, revealing that the experimentation adopted is quite adequate. On the other hand, the progeny $\mathrm{x}$ location interaction was shown to be significant, although the correlation of genotypic performance across the environments was high. This shows that the genotype $x$ environment interaction is not problematic for the improvement of teak in that country.

In Costa Rica, individual heritability estimates of good magnitudes, ranging from $25 \%$ to $30 \%$, have been obtained for growth traits and timber quality. These figures show a very favorable situation for selection and very good perspectives for the teak breeding program in Costa Rica. Genetic value predictions by the BLUP methodology have been adopted and genetic gains of around $20 \%$ were estimated (Resende 2007).

Provenance, progeny and clone tests repeated in some places are urgently recommended for Brazil, aiming to form an experimental network as a basis for a breeding program. Specifically in the case of teak, several provenance tests have been performed worldwide. In Brazil, however, the information for selection of provenances to be planted is based on the use of data generated in other countries. Basically, there are two teak provenances used in Brazil. The first and most important in planted area is from the variety Tennasserim originated from Myamar and initially planted in Trinidad and Tobago. The second most important comes from Sri Lanka and was initially planted in Panama. The need for provenance tests is corroborated by the superiority of some imported clones. Individuals with similar volume presented by these clones are not found in the seeds produced in Brazil, indicating that they must come from more adequate provenances.

While teak is easy to clone, in Brazil this technique has not been adopted consistently. The few clonal plantations are being made by micro-propagated seedlings, whose cost prevents their commercial use. However, some companies are structuring themselves to establish teak cloning systems at a large scale, which should become models for the widespread adoption of this technique. 


\section{Melhoramento genético de espécies florestais}

RESUMO - O setor florestal brasileiro é considerado um dos mais desenvolvidos do mundo, sendo a base para importantes segmentos da produção industrial, que usa a madeira como fonte de matéria prima. O melhoramento florestal tem desempenhado papel importante no aumento da competitividade do setor de base florestal brasileiro, sobretudo por seus reflexos positivos no aumento da adaptação, da produtividade e da qualidade da madeira. Apesar da importância de outras espécies florestais, como Schizolobium, Araucaria, Populus $e$ Hevea, os principais gêneros sob melhoramento no País são Eucalyptus, Pinus, Acacia $e$ Tectona. São utilizados por indústrias como a de polpa e papel, siderurgia, tanino, madeira serrada, além da produção de cavacos para exportação, constituindo uma importante fonte de divisas para a economia do País, além de seus positivos efeitos sociais e ambientais. Este trabalho apresenta uma abordagem genérica de aspectos do melhoramento genético desses quatros gêneros para os quais se desenvolvem programas de melhoramento no Brasil.

Palavras-chave: melhoramento, eucalipto, Pinus, acácia negra, teca.

\section{REFERENCES}

ABRAF - Associação brasileira de produtores de florestas plantadas (2010) Anuário estatístico da ABRAF 2010. Ano base 2009. Available at <http://www.abraflor.org.br/estatisticas/ABRAF10BR/controle.html> Assessed in April, 2011.

Assis TF (1996) Melhoramento genético do eucalipto. Informe Agropecuário 18: 32-51.

Assis TF (2000) Production and use of Eucalyptus hybrids for industrial purposes. In Dungey HS, Dieters MJ and Nikles DG (eds.) Hybrid breeding and genetics of forest trees: QFRI/ CRC-SPF Symposium. Department of Primary Industries, Noosa, p. 63-74

Assis TF (2001) Melhoramento para produtividade e qualidade de celulose de fibra curta. In Resende MDV (ed.) Workshop sobre melhoramento de espécies florestais e palmáceas no Brasil. Embrapa Florestas, Curitiba, p. 193-214.

Assis TF, Rosa OP and Gonçalves SI (1992) Propagação clonal de Eucalyptus por microestaquia. In Anais do $7^{\circ}$ congresso florestal estadual, Nova Prata. UFSM, Santa Maria, p. 824836 .

Costa RB and Resende MDV (2001) Melhoramento de espécies alternativas para o centro-oeste - teca. In Resende MDV (ed.) Anais do workshop sobre melhoramento de espécies florestais e palmáceas no Brasil. Embrapa Florestas, Colombo, p. 153-167

Costa RB, Resende MDV and Silva VSM (2007) Experimentação e seleção no melhoramento da Teca. Floresta e Ambiente 14: 76-92.

Ferreira M and Santos PET (1997) Melhoramento genético florestal dos eucaliptos no Brasil - breve histórico e perspectivas. In Proceedings of IUFRO conference on silviculture and improvement of eucalypts. v. 1., Embrapa/CNPF, Salvador/ Colombo, p. 14-34.
Fonseca SM, Resende MDV, Alfenas AC, Guimarães LMS, Assis TF and Grattapaglia D (2010) Manual prático de melhoramento genético do eucalipto. Editora UFV, Viçosa, 200p.

Grattapaglia D and Resende MDV (2010) Genomic selection in forest tree breeding. Tree Genetics \& Genomes, DOI: 10.1007/s 1 1295-010-0328-4.

Higashi EN, Silveira RLVA, Gonçalves AN (2000) Monitoramento nutricional e fertilização em macro, mini e microjardim clonal de Eucalyptus. In Gonçalves JLM and Benedetti V (eds.) Nutrição e fertilização florestal. IPEF, Piracicaba, p. 191217.

Kageyama PY and Vencovsky R (1983) Variação genética em progênies de uma população de Eucalyptus grandis Hill Maiden. IPEF 24: 9-26.

Resende MDV (1999) Melhoramento de essências florestais. In Borém A (ed.) Melhoramento de espécies cultivadas. Editora UFV, Viçosa, p. 589-647.

Resende MDV (2002) Genética biométrica e estatística no melhoramento de plantas perenes. Embrapa Informação Tecnológica, Brasília, 975p.

Resende MDV (2007) Matemática e estatística na análise de experimentos e no melhoramento genético. Embrapa Florestas, Colombo, 435p.

Resende MDV and Barbosa MHP (2005) Melhoramento genético de plantas de propagação assexuada. Embrapa Florestas, Colombo, 130p.

Resende MDV, Lopes PS, Silva RL and Pires IE (2008) Seleção genômica ampla (GWS) e maximização da eficiência do melhoramento genético. Pesquisa Florestal Brasileira 56: 63-78.

Xavier A and Comério J (1996) Microestaquia: uma maximização da micropropagação de Eucalyptus. Revista Árvore 20: 9-16. 